\title{
Neotectonic Activity from the Upper Reaches of the Arabian Gulf and Possibilities of New Oil Fields ${ }^{1}$
}

\author{
V. K. Sissakian ${ }^{a}$, A. D. Abdul Ahad ${ }^{b}$, N. Al-Ansaric, *, and S. Knutsson ${ }^{c}$ \\ ${ }^{a}$ Faculty of Geology, University of Kurdistan, Erbil, KRG Iraq \\ ${ }^{b}$ Iraq Geological Survey, Baghdad, Iraq \\ ${ }^{c}$ Department of Civil, Environmental and Natural Resources Engineering, Lulea University of Technology, Lulea, 97187 Sweden \\ *e-mail: nadhir.alansari@ltu.se \\ Received September 30, 2016
}

\begin{abstract}
Upper reaches of the Arabian Gulf consist of different types of fine sediments including the vast Mesopotamia Plain sediments, tidal flat sediments and estuarine sabkha sediments. The height of the plain starts from zero meter and increases northwards to three meters with extremely gentle gradient. The vast plain to the north of the Arabian Gulf is drained by Shat Al-Arab (Shat means river in Iraqi slang language) and Khor Al-Zubair (Khor means estuary). The former drains the extreme eastern part of the plain; whereas, the latter drains the western part. Shat Al-Arab is the resultant of confluence of the Tigris and Euphrates rivers near Al-Qurna town; about $160 \mathrm{~km}$ north of the Arabian Gulf mouth at Al-Fao town; whereas, the length of Khor $\mathrm{Al}$-Zubair is about $50 \mathrm{~km}$; as measured from Um Qasir Harbor. The drainage system around Khor Al-Zubair is extremely fine dendritic; whereas around Shat Al-Arab is almost parallel running from both sides of the river towards the river; almost perpendicularly. The fine dendritic drainage around Khor Al-Zubair shows clear recent erosional activity, beside water divides, abandoned irrigation channels and dislocated irrigational channels and estuarine distributaries; all are good indication for a Neotectonic activity in the region. These may indicate the presence of subsurface anticlines, which may represent oil fields; since tens of subsurface anticlines occur in near surroundings, which are oil fields.
\end{abstract}

Keywords: Arabian Gulf, active fault, neotectonic activity, sediments, subsurface anticlines, oil fields, Iraq DOI: $10.1134 / \mathrm{S} 0016852118020103$

\section{INTRODUCTION}

The Arabian Gulf is the extension of the Indian Ocean (Gulf of Oman) through the Strait of Hormuz, it lies between Iran to the northeast and the Arabian Peninsula to the southwest and Iraq to the north. The extreme southern part of the Iraqi territory represents the upper reaches of the Arabian Gulf that forms a flat plain, which represents; partly the extension of the Mesopotamia Plain. The flat plain; however, also includes part of the tidal flat and estuarine sabkha; both cover considerable part of the studied area.

The studied area is located in the extreme southern part of Iraq and extends slightly towards the Arabian Gulf and small area within the Kuwaiti territory (Fig. 1). Previous work dealt with various geological aspects. The most comprehensive studies about the area are the following.

The gulf is a tectonic basin of late Pliocene to Pleistocene age, whose morphology is greatly influenced by the tectonic style [15].

\footnotetext{
${ }^{1}$ The article is published in the original.
}

At the end of the last glacial period, a major marine transgression inundated the head of the Persian Gulf to a position as much as $400 \mathrm{~km}$ inland from the present shoreline [2]. After 6000 B.P., the Shatt al-Arab delta prograded southward to its current position.

Five physiographic subdivisions in the sediments of Shat Al-Arab Delta were recognised and described in [3].

Mesopotamia Plain was considered as a huge aggradational (accumulational) geomorphologic unit, where the fluvial, lacustrine, and Aeolian landforms prevail [23]. Estuarine and marine forms also existed, but these were restricted to the extreme southeastern reaches of the plain [23].

Tectonic evolution of the Mesopotamia Plain presented in [6] and considered it as a mobile tectonic zone that contains several buried structures including folds, faults and diapiric structures.

Stratigraphic units of the Mesopotamia Plain and mentioned units of different origins, such as fluvial, lacustrine, marine, estuarine, Aeolian and anthropogenic reported in [24]. 

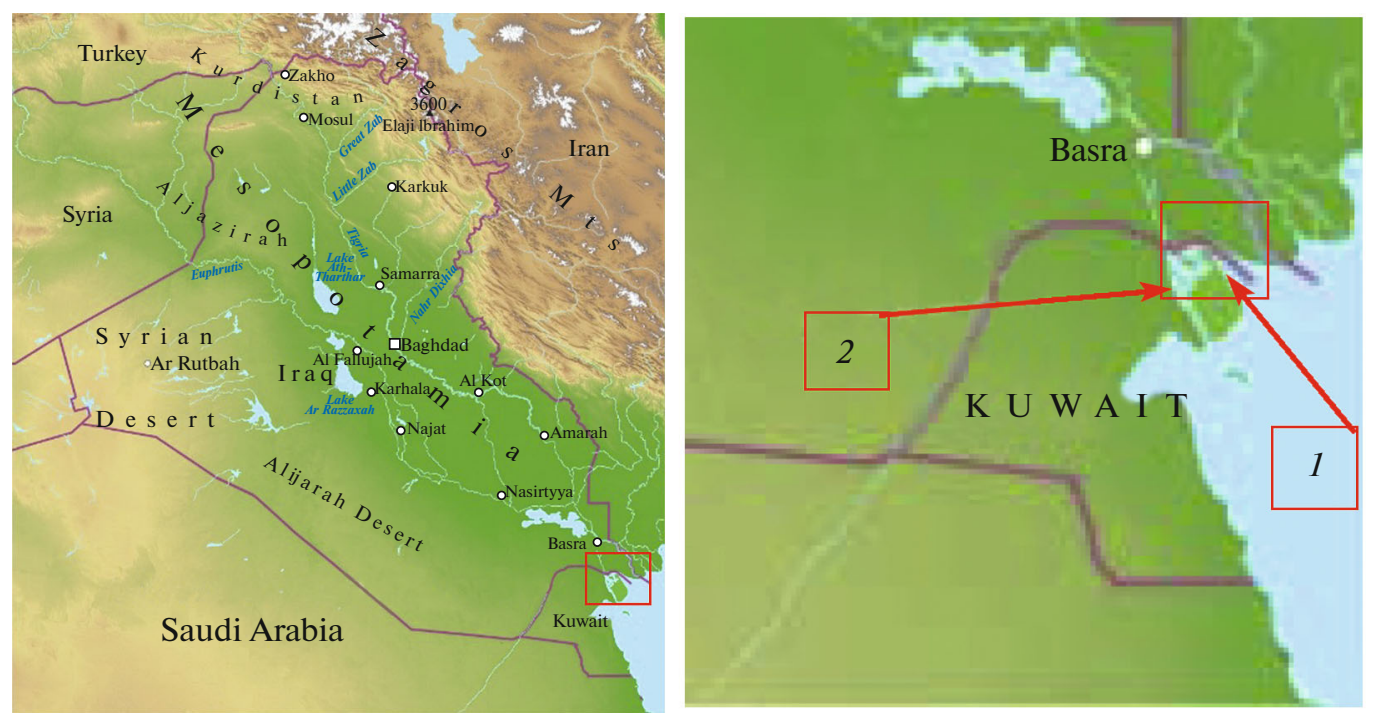

Fig. 1. Geographical map of the study area. (1) Shat Al-Arab, (2) Khor Al-Zubiar.

Sediments of the Arabian Gulf in Kuwait were based on the carbon dating of these sediments [21], the last phase of the relative sea level drop likely occurred around 1800 years ago.

None of the research executed about this area dealt with the neotectonic activities and the aim of this study is to elucidate the evidences that prove the presence of Neotectonic activity in the studied area.

Using the available topographical and geological maps of different scales the parameters of the studied area were measured. No field work was carried out in the current study; this is attributed to the accessibility of the area, which is almost inundated by the sea water and needs special machinery to reach the area and make trenches. Therefore, all presented data is achieved from the interpretation of the satellite images depending on the experience of the authors; in this aspect and using many concerned studies $[9,10,12,13]$.

\section{GEOLOGICAL SETTING}

The geomorphology, structural geology and tectonics, and stratigraphy of the study area are given briefly depending mainly on best available data $[6,18$, $23,24]$.

\section{Geomorphology}

The studied area is characterized by its flat nature with zero height along the shore line increasing northwards to about $3 \mathrm{~m}$ with very gentle gradient. The main geomorphological features are flood plain of Shat AlhArab that includes two main abandoned channels (Fig. 2), the tidal flat plain and Sabkha plain [24]. Moreover, the fine dendritic drainage pattern of Khor Al-Zubair (estuary) with clear head wards erosional features (Fig. 3). Some of these drainage patterns exhibit abnormal meanderings and bending's indicating Neotectonic activity; such indications are also confirmed by many researchers worldwide $[9,10,12]$.

\section{Tectonics and Structural Geology}

The studied area lies within the Mesopotamia Plain of the Outer Platform [6]. Part of Mesopotamia Foredeep within the tectonic framework of Iraq and large subsiding basin covered by thick Quaternary sediments of the Tigris and Euphrates Rivers with their tributaries and distributaries represented by Shat Al-Arab.

The whole studied area is covered by Holocene allvial sediments with marine influence in extreme southern marginal part [19, 23]. The sediments are mainly of clay and silt with sabkha in the tidal flat area (Fig. 4).

\section{EVOLUTION OF THE ARABIAN GULF}

The evolution history of the upper reaches of the Arabian Gulf is briefed hereinafter. At the end of the last glacial period, a major marine transgression inundated the head of the Arabian Gulf to a position as much as $400 \mathrm{~km}$ inland from the present shoreline.

The sea level fell by as much as $120 \mathrm{~m}$ during the Pleistocene, emptying the Gulf; river valleys were eroded down the slopes. The sea then cut a series of platforms, at its level of maximum retreat and at times of relative standstill during the post-glacial rise. The Recent unconsolidated sediments are the product of the post-glacial Flandrian transgression, which began about (18000-16000) years B.P. and reached its present level about 5000 years B.P. [4]. These sediments are expected eventually to smooth out the pre-Recent topography by filling up the depressions and extending over the highs [15]. This assumption also confirms that 


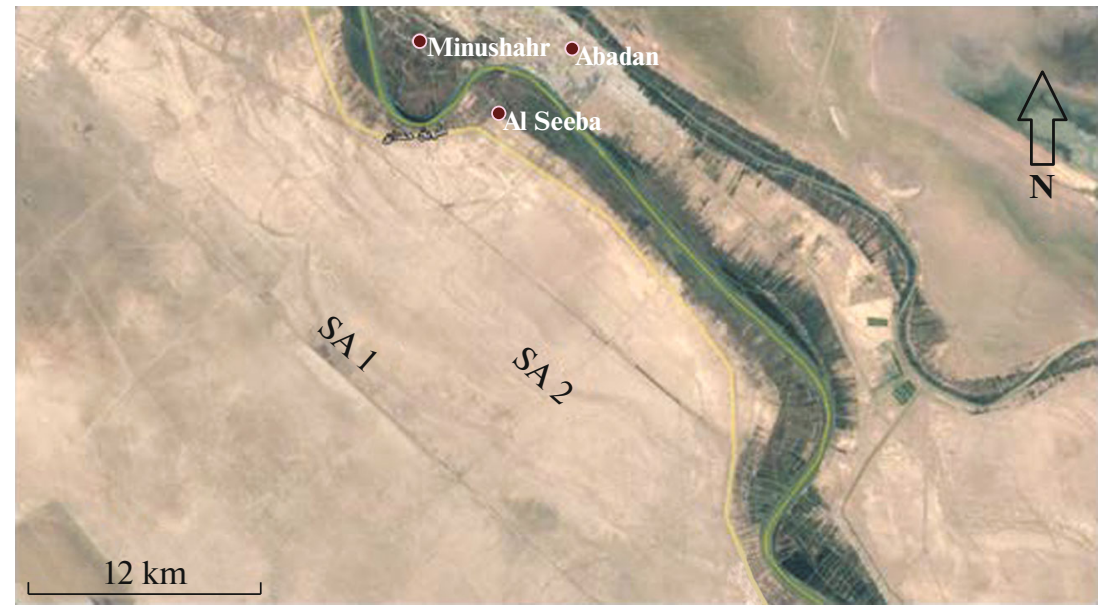

Fig. 2. The two abandoned channels of Shat Al-Arab (SA 1 and SA 2).

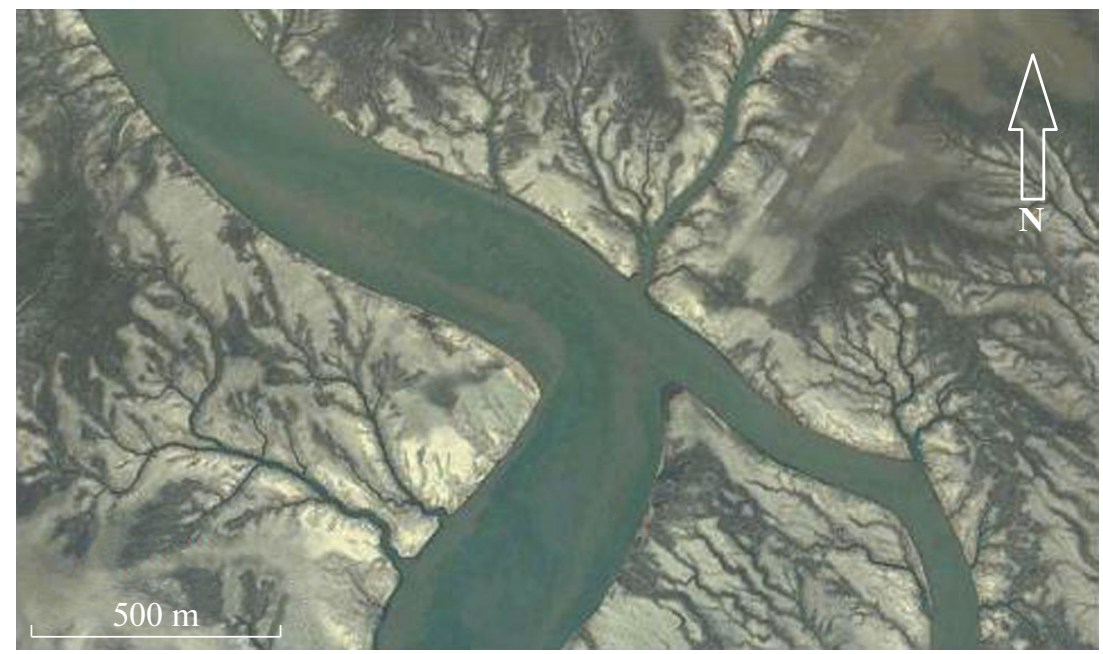

Fig. 3. The fine dendritic drainage pattern within Khour Al-Zubair (Estuary).

the whole study area and near surroundings are quite flat area with extremely gentle gradient descending towards the gulf.

The mid-late Holocene drop in relative sea level has resulted in the deposition and progradation of coastal facies along the northwestern part of the Arabian Gulf. These exposures are overlain by the recent continental deposits of rubbles. Based on the carbon dating of these sediments, the last phase of the relative sea level drop likely occurred around 1800 years ago. Neotectonics activity of local structuring, due to the regional northeast ward movement of the Arabian Plate under the Zagros Fold Belt (Fig. 5), might have a role in this sea receding [12]. However, climatic changes and transported sediments by the rivers may have contributed too in the development of the described features as evidences for Neotectonics activity.
Estuaries are developed as the result of the interaction between geomorphological structures and dynamic processes and as a result of the tidal effect on the unconsolidated sediments, therefore they are marine as well as riverine. Local modifications are also intervene; they derive from relative sea-level changes, climate conditions and human activities [7].

Neotectonic activity also may be included as a factor as well; besides the other parameters. It may cause changes in the sedimentation rates, result in the creation of new geomorphological features (spits, dunes, cheniers, marshes, levees, alluvial soils), sea-level oscillations. In the studied area; however, marshes, levees, alluvial soils and cheniers are common.

Moreover, it was stated in [16] that they contend that sustained neotectonic activity in the estuary, as in geologically comparable areas elsewhere in the world, has contributed significantly to the sedimentary infill- 


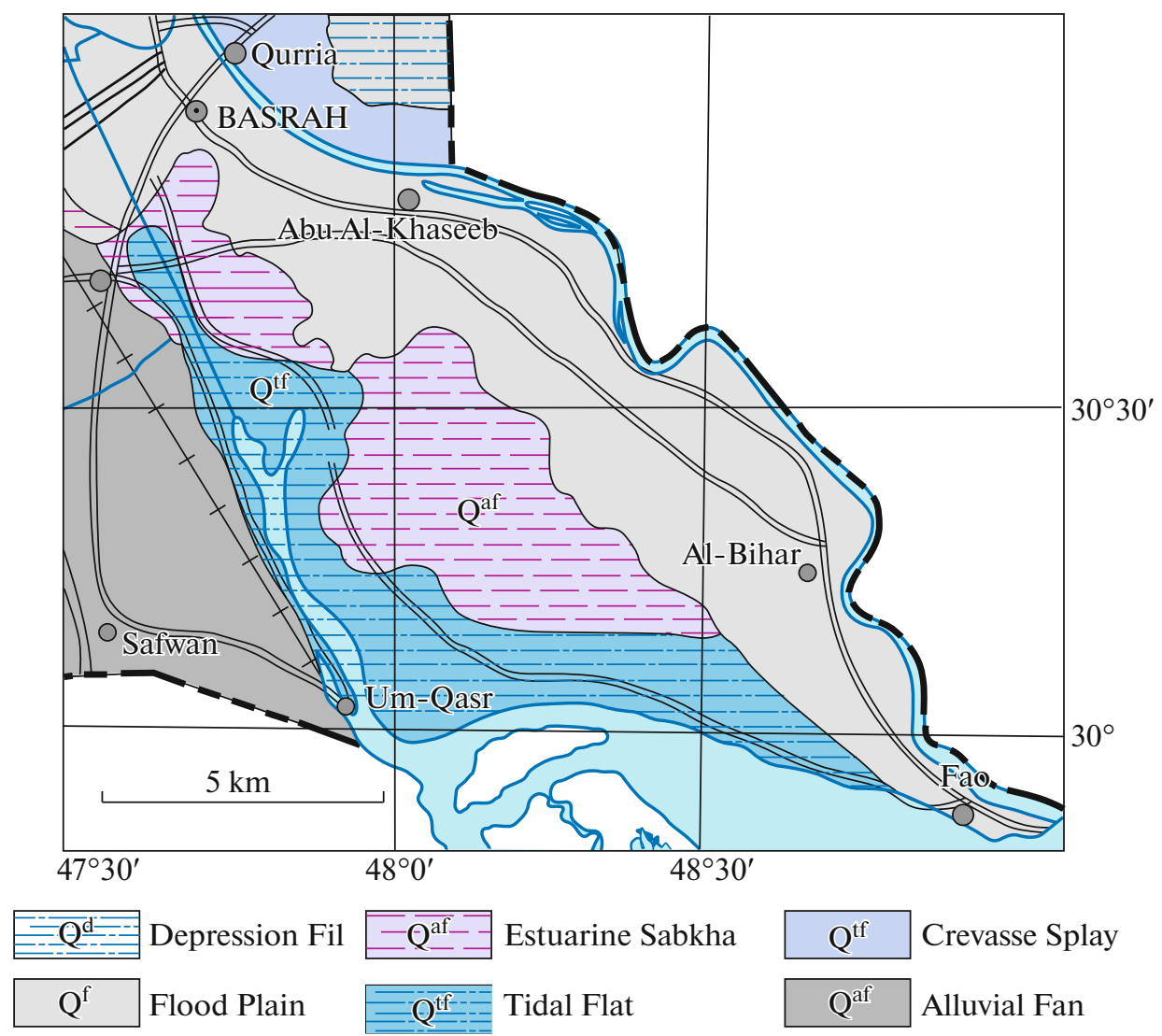

Fig. 4. Geological map of the studied area (after [18]).

ing and geomorphological configuration of the basin during the Holocene.

\section{NEOTECTONICS EVIDENCES}

The following aspects are good indications for the Neotectonic activity in the studied area. The experience of the authors and analysis data from $[9,10,12$, $13]$ are used to indicate the evidences.

\section{Dissection of Old Irrigation Channels}

A large irrigation channel running NE-SW (Figs. 6, 7) is abandoned and is dissected by many estuarine tributaries. The digging data of the channel is unknown; however, clear differences can be seen along the channel and the tributaries that had happened during about 50 years, which is the date difference between the two scenes (Fig. 6, 1962 and 2016, respectively, points $\mathrm{A}, \mathrm{A} 1, \mathrm{~B}, \mathrm{~B} 1, \mathrm{C}, \mathrm{C} 1)$.

The irrigation channel was abandoned most probably due to uplift of the area due to Neotectonic movement, however, the abandonment may had happened due to siltation. Because the whole studied area and surroundings suffer from Neotectonic activ- ity $[6,18,19]$, therefore, the abandonment due to siltation is less likely.

The dissection of the abandoned irrigation channel by many estuarine tributaries is another indication for Neotectonic activity. When the irrigation channel was dug no estuarine tributaries were found there.

\section{Active Faults}

Active faults are another indication for Neotectonic acitivities $[9,10,12-14]$. Many active faults that have clear evidences are shown (Figs. 6-8). The straight line that have cut in the sediments (Fig. 6, points B and B1) and have formed water shade; towards northwest (Fig. 6, points $\mathrm{C}$ and $\mathrm{C} 1$ ). The western block is uplifted; this is evidenced from the gradient of the slope, which is higher in the west as compared to the east side. Moreover, the thin lines that intersect drainage system (Fig. 6, NW of B) and the different frequency of erosional channels on both sides of the line between $\mathrm{B}$ and $\mathrm{C}$, which are possible evidence of vertical offset (Fig. 8, points A, B, C).

The right angle bends (Fig. 7, points A and B) of the main tributary and the slight shift in the abandoned irrigation channel (Fig. 7, point C) are other indications for active faults. The eastern block is most 

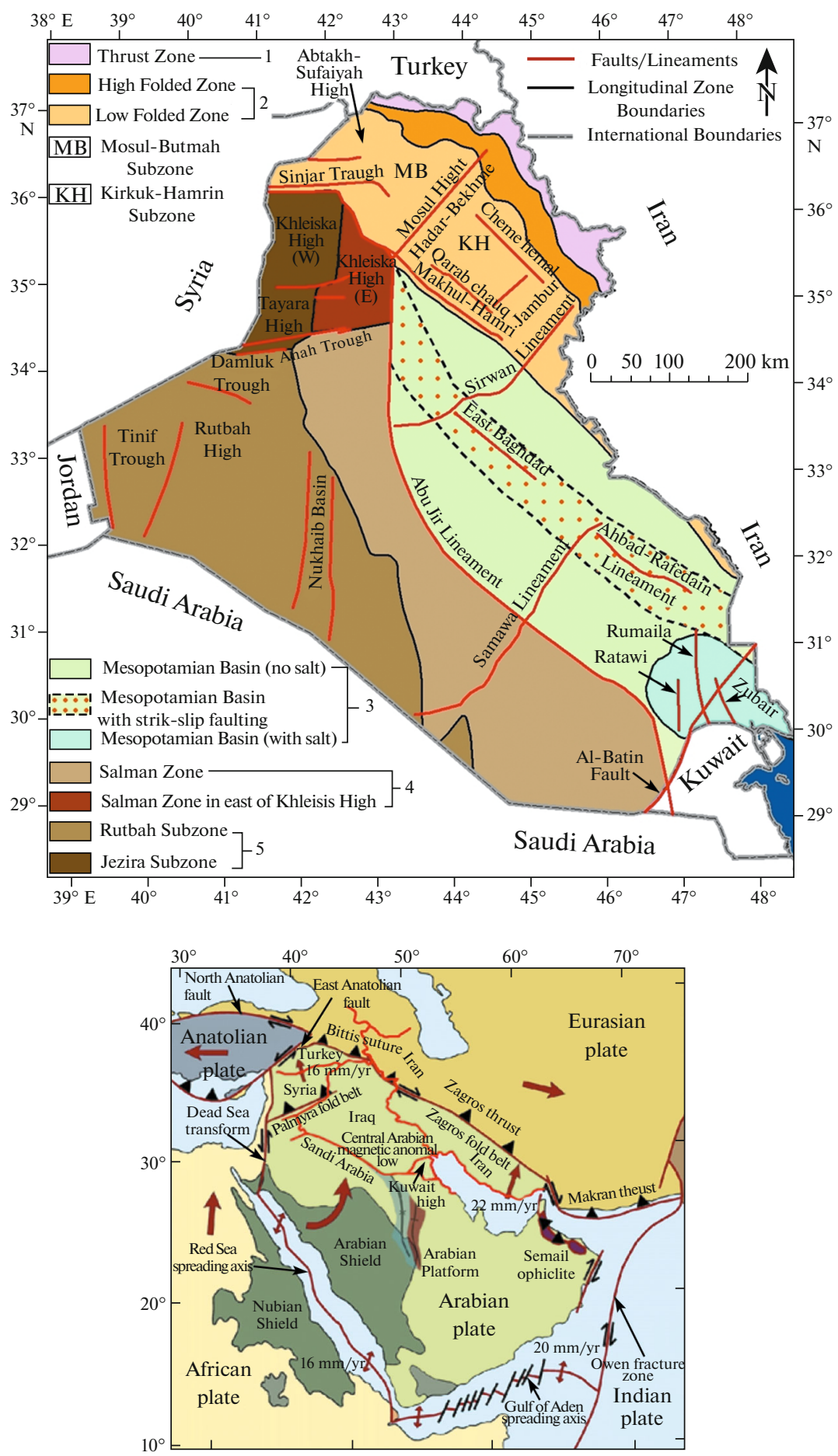

Fig. 5. Top, tectonic map of Iraq (top) (after [1]); bottom, tectonic map of Saudi Arabia and near surrounding, including the studied area (bottom) (after [8]).

probably the down thrown side, as evidenced from the initiated fine drainage along the eastern side of the main channel.

The developed straight alignment (Fig. 8, points A, $\mathrm{B}, \mathrm{C}$ ) in the soft sediments that have followed by fine drainage may indicate an active fault; otherwise the fine tributary wouldn't show such straight line with different flow directions.

\section{Abadnoned Shat Al-Arab Courses}

Shat Al-Arab shows clear migration eastwards abandoning its main course (Figs. 2, 9). Such migra- 

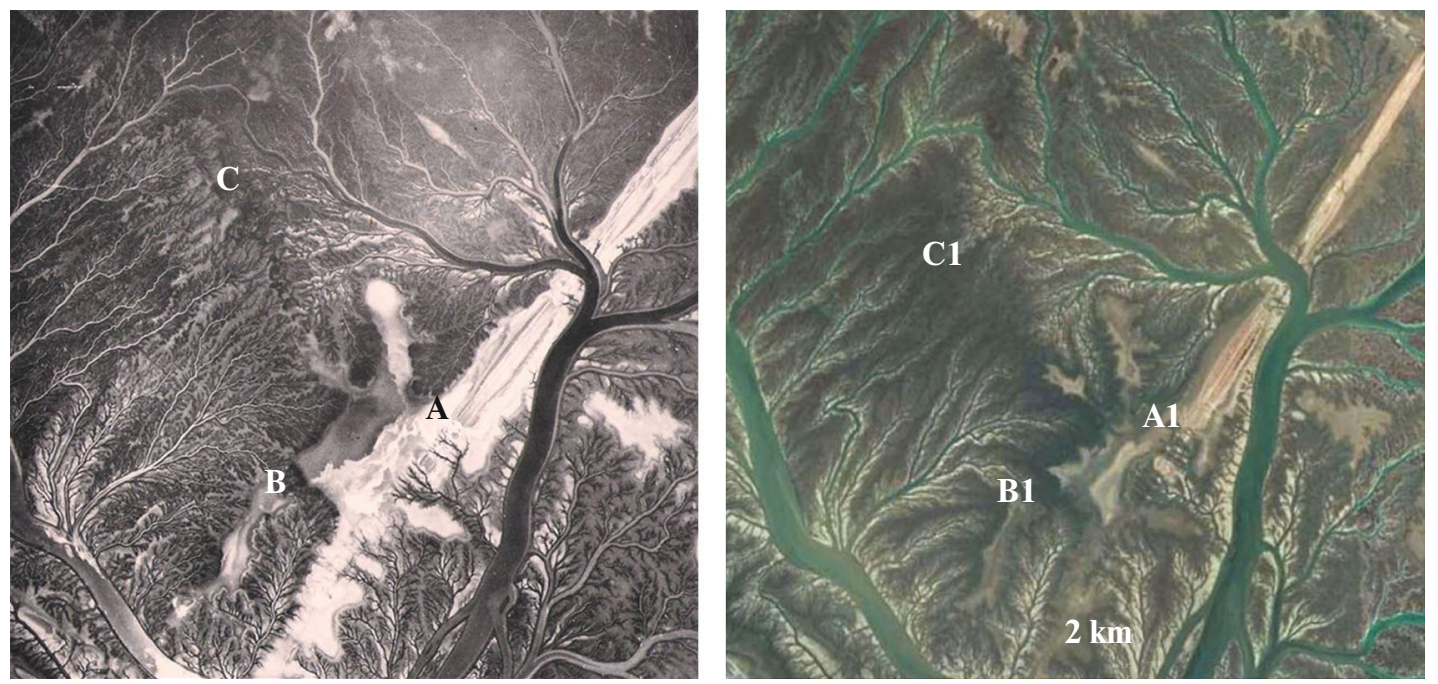

Fig. 6. Left, aerial photograph, General Directorate of Survey, 1962); right, satellite image, 2006. The tidal channels system of Khor Al-Zubair and head of the Arabian Gulf.

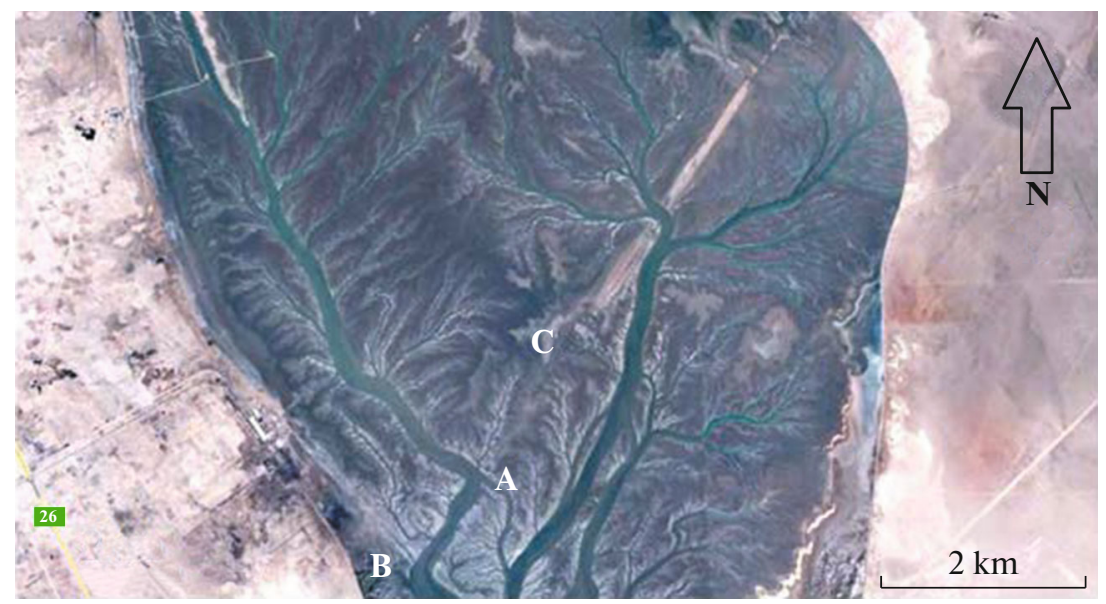

Fig. 7. Khor Al-Zubair, note the abandoned irrigation channel.

tion of the Tigris River within the Mesopotamia Plain indicates clear Neotectonic activity [6]. The upward movement within the studied area and surroundings has caused migration of Shat Al-Arab course eastwards in successive movements, which indicate Neotectonic activity.

Right Angle Bends of the Drainage. Usually, the valleys did not exhibit right angle bends; unless they are controlled tectonically. Therefore, those right angle bends in the drainage system of different orders (Figs. 7, 10) are clear indications for Neotectonic activity; otherwise no such right angle bends will be developed in such soft unconsolidated sediments. Moreover, the presence.

Abnormal Drainage Systems. The Estuarine and tidal flat areas are flat lying plains very gently sloping northwards. The topographic contours are almost par- allel to the shape of the Arabian Gulf mouth, which is in form if a wide crescent. Therefore, any local differences in heights are considered as anomalous and developed due to local uplifts representing Neotectonic activity.

The set of parallel estuarine valleys is developed (Fig. 11, point A), that have very fine dendritic drainage both upstream and downstream (Fig. 11, points $\mathrm{C}$ and $\mathrm{D}$, respectively). Towards the west; however, the estuarine valleys exhibit normal dendritic pattern with a water divide in between two systems (Fig. 11, point E). These two different drainage systems with a water divide in between are abnormal behaviour for drainage in soft sediments. Therefore, they should be under tectonic control consequently indicating Neotectonic activity. 


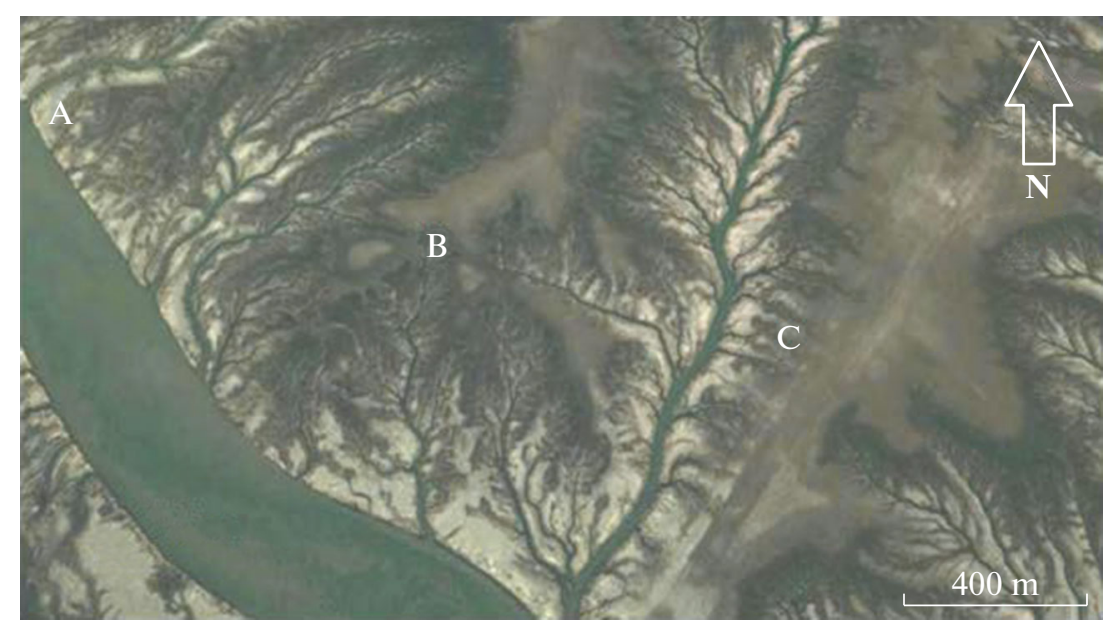

Fig. 8. Alignment that may indicate active fault, which is followed by straight drainage.

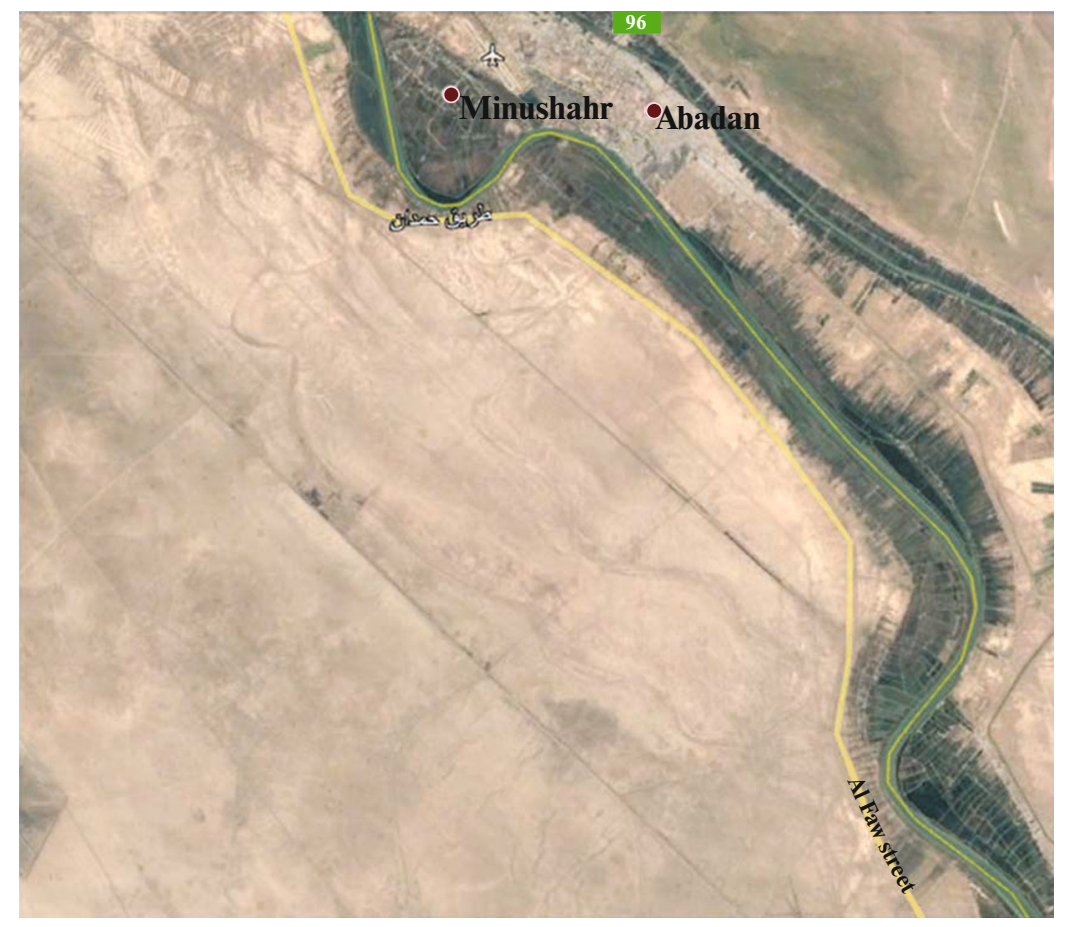

Fig. 9. Abandoned courses of Shat Al-Arab.

The estuarine valleys are bifurcating downstream ward (Fig. 12, points A, B) which are also abnormal since valleys usually bifurcate upstream wards. Therefore, this abnormal behaviour should be due to local uplift. The presence of local water divides in different directions (Fig. 12, points C, D, E) also indicates local uplifts that indicate Neotectonic activity.

Two estuary branches are exhibiting inverse Ushaped drainage downstream (Fig. 13, points A and B) and join together in abnormal drainage form. Moreover, finer drainage branch no.1 merges into the main branch after exhibiting right angle bend (Fig. 13, point C), whereas branch no. 2 flows normally to the main branch. If branch no. 1 was not controlled tectonically, then it would merge to the same branch in which branch no. 2 is merging. Therefore, it should be controlled tectonically indicating Neotectonic activity.

\section{DISCUSSION}

The studied area and near surroundings is covered by fine unconsolidated fine sediments mainly of alluvial origin and that of tidal flat sediments; with estuarine sabkha. These all form flat plain starting from 


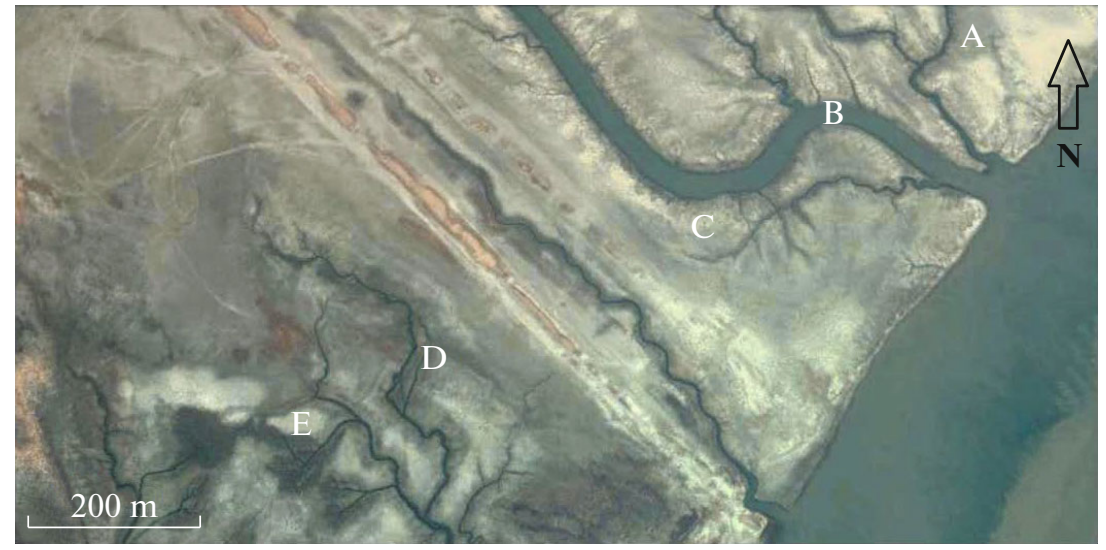

Fig. 10. Right angle bends in the drainage system (A, B, C, D and E).

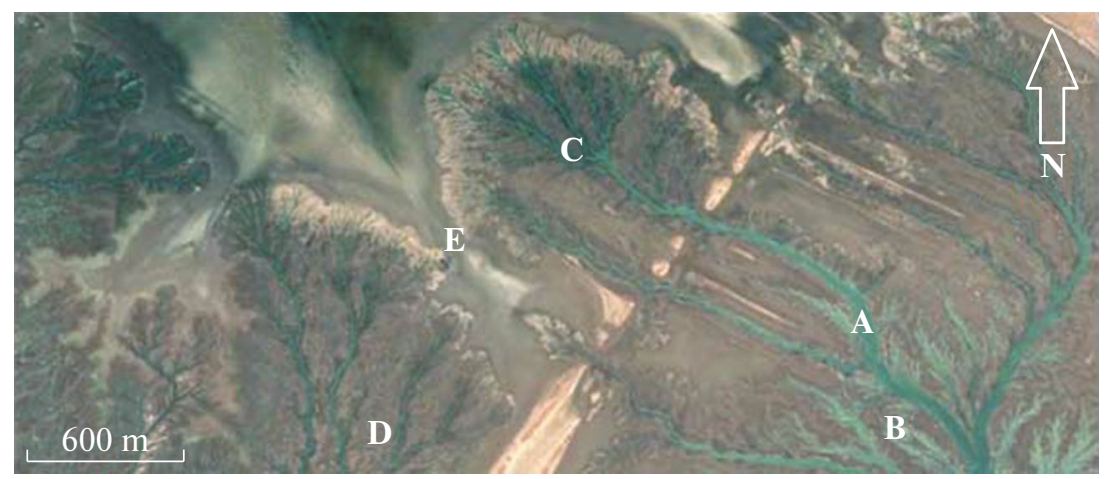

Fig. 11. Abnormal drainage system.

zero meter (a.s.l.) and starts increasing in elevation with very gentle gradient. This plain is dissected; in the western part by Khor Al-Zubiar estuary drainage system that has very fine dendritic pattern with some abandoned old irrigation channels. This flat plain exhibits local water divides that have almost $\mathrm{N}-\mathrm{S}$ trend, which is parallel to the main Zagros folding system; in that particular area.

The developed water divides (Figs. 6-8, 11), which are oriented in NW-SE trend are controlled tectonically; therefore, are considered as Neotectonic activity; otherwise no water divide should be developed in flat deltaic plains, since the elevation differences is within fractions of one meter. The Neotectonic activity is attributed either to local growth of subsurface folds or to fluid overpressure within the sedimentary wedge of coastal plain deposits (Deltaic unit) [16]. The former case is confirmed by the presence of tens of subsurface anticlines with NW-SE trend, south and east of the studied area $[5,6]$. The latter case, however, is a well-known geological event in sedimentary and deltaic basins around the world and are often located near subsurface reservoirs of hydrocarbon deposits or salt domes [7, 11].
The abandoned two courses of Shat A-Arab (Figs. 2, 9) are also good indication for Neotectonic activity. Such abandoned courses of the Tigris River were recognized in the central part of the Mesopotamian Plain [6]. The Tigris River was successively shifted there (two abandoned courses) towards northeast because the growing subsurface anticlines were oriented in NW-SE trend. However, in the studied area the Shat Al-Arab is shifted eastwards, this is attributed to the trend of the subsurface anticlines in the surroundings of the studied area where the trend is NW-SE.

The abandoned irrigation channels (Figs. 3, 6-11) are good indication that the studied area and near surroundings are uplifted from the original elevation when the irrigation channels were dug; otherwise they should not be abandoned. The siltation; however, also may fill the channels, but since the water flows forward and backward in the channels; due to the tide action; therefore, the siltation in the channels will be less likely.

The right angle bends of the drainage (Figs. 3, 7, $10,11)$ indicates that the drainage is controlled tectonically; following weakness zones. The right angles' bends are oriented in NE-SW trend, which may indi- 


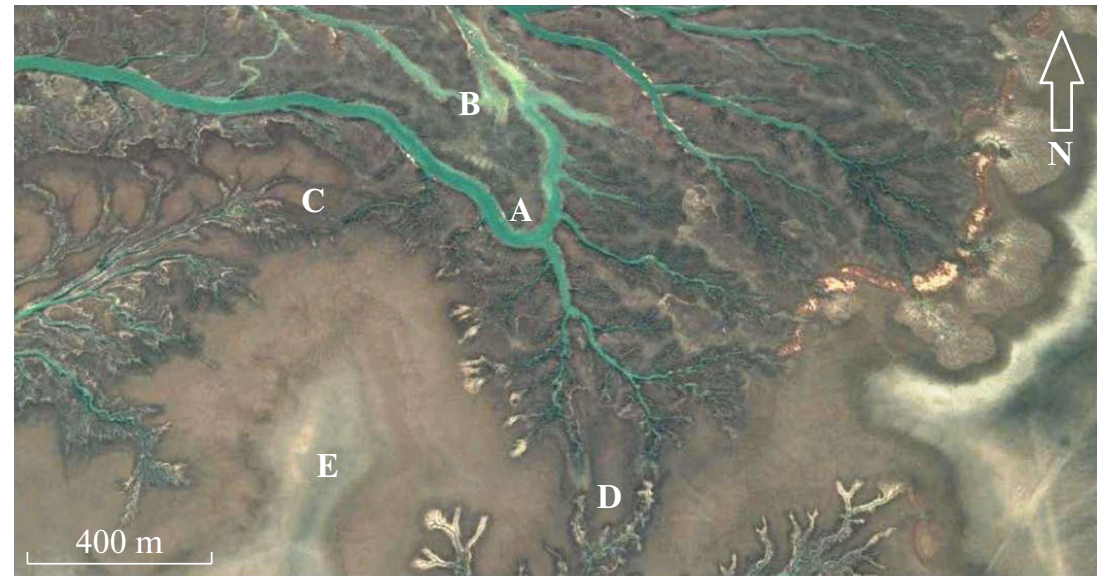

Fig. 12. Abnormal drainage system.

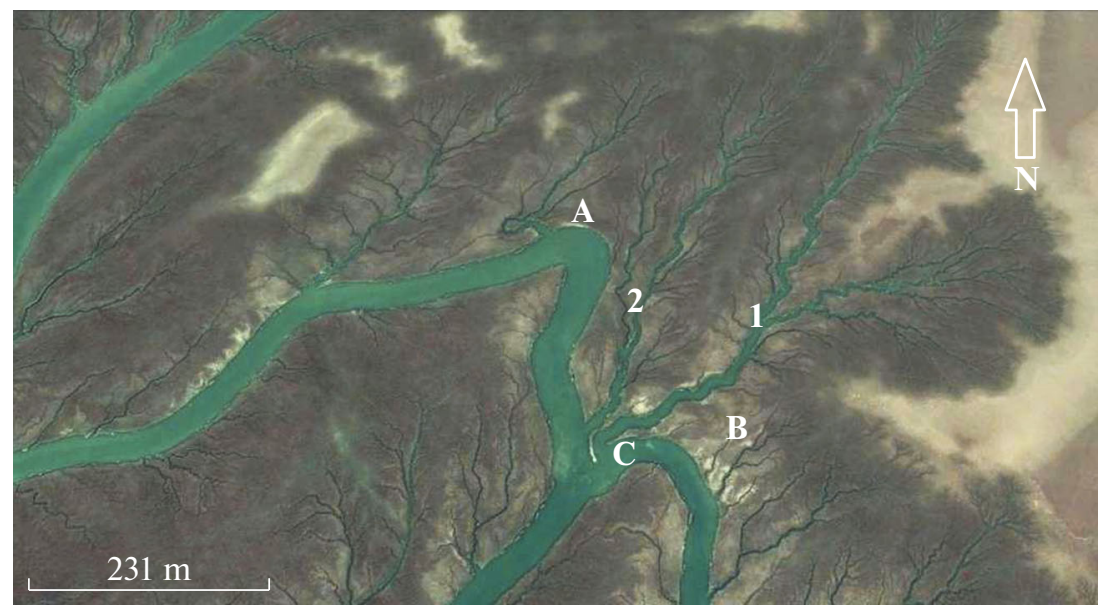

Fig. 13. Abnormal drainage system.

cate that they are tectonically controlled; since the main tectonic trend in the studied area and near surroundings is $\mathrm{NW}-\mathrm{SE}$.

The abnormal drainage forms; like bifurcation of the drainage downstream wards (Fig. 12, points A and B), changing the drainage pattern from fine dendritic to parallel pattern (Fig. 11), being oriented in straight alignments (Fig. 8, points A, B, C; Fig. 11, points A, B and $\mathrm{C}$ ), and exhibiting inverse U-shaped drainage downstream (Fig. 13, points A, B) and abnormal merging of fine branch to main one (Fig. 13, branch no. 1 at point C). All these forms wouldn't be developed unless they are controlled tectonically; consequently, indicate Neotectonic activity.

We have compiled all the interpreted data about the Neotectonic indications in one image (Fig. 14). All the interpreted data are traced on one single image that shows the majority of the study area. This one single image shows more clearly the trends of the interpreted data; accordingly, we have found that two main trends exist in the study area; NW-SE and NE-SW.

\section{CONCLUSIONS}

Detailed analysis of the aerial photographs and satellite images, and topographic maps enabled us to identify a number of geomorphological anomalies, such as abnormal drainages, subdued morphologies, abandoned irrigation channels, abandoned river courses, local water divides and erosive forms.

All these aspects are controlled tectonically revealing Neotectonic activity in the fine unconsolidated alluvial and deltaic sediments. The trends of the recognized features are NW-SE and NE-SW, the former is parallel to the main Zagros fold trend in the studied area and surroundings, whereas the latter represents the compressional trend of the collision between the Arabian and Eurasian plates. 


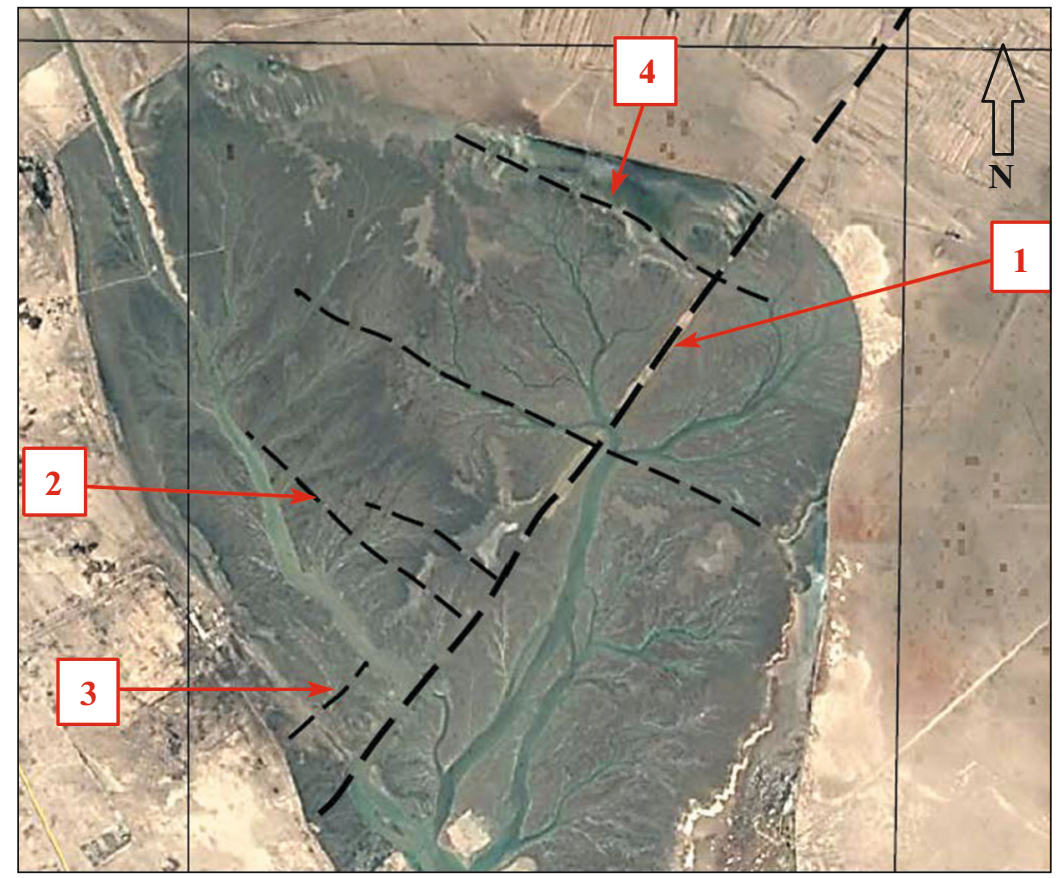

Fig. 14. The study area showing the interpreted features, which indicate Neotectonic activity. Fault indicated by arrow 1 is depicted in Figs. 6 and 7; 2, Fig. 8; 3 Fig. 10; 4, Fig. 11.

The Neotectonic activity is attributed to the growth of subsurface anticlines and/or to fluid overpressure within the sedimentary wedge of coastal plain sediments in the Mesopotamian Plain especially in the middle and southern part of it and near subsurface hydrocarbon reservoirs. It is worth mentioning that towards west and north of the studied area many large oil fields are present such as Rumaila, Zubair, Naher Umr, Majnoon.

The confirmation of the Neotectonic activity indicates the presence of areas under uplift movements. Accordingly, they may indicate the presence of subsurface anticlines, which may represent oil fields since tens of subsurface anticlines occur in near surroundings, which are oil fields.

\section{ACKNOWLEDGMENTS}

The authors would like to express their sincere thanks to the reviewers for their fruitful comments, which have amended the manuscript. The Iraq Geological Survey gratefully supplied us with maps and imageries.

\section{REFERENCES}

1. A. A. M. Aqrawi, J. C. Goff, A. D. Horbury, and F. N. Sadooni, The Petroleum Geology of Iraq (Scientific Press Ltd., Beakonsfield, U.K., 2010).

2. G. A. Cooke, "Reconstruction of the Holocene coastline of Mesopotamia," Geoarchaeology 2, 15-28 (1987). doi 10.1002/gea.3340020102
3. S. A. Darmoian and K. Lindqvist, "Sediments in the estuarine environment of the tigris/euphrates delta; Iraq; Arabian Gulf," Geol. J. 23, 15-37 (1988). doi 10.1002/gj.3350230102

4. R. W. Fairbridge, "Eustatic changes in sea-level," in Phys. Chem. Earth 4, 99-185 (1961).

5. S. F. Fouad, Tectonic Map of Iraq, Scale $1: 1000000$, 3rd ed. (Iraq Geol. Surv., Baghdad, 2012).

6. S. F. Fouad and V. K. Sissakian, "Tectonic and structural evolution of the Mesopotamia Plain," in Geology of the Mesopotamia Plain, Spec. Is. No. 4 of Iraqi Bull. Geol. Min. (2011), pp. 33-46.

7. Salt Tectonics: A Global Perspective, Vol. 65 of $A A P G$ Mem., Ed. by M. P. A. Jackson, D. G. Roberts, and S. Snelson (AAPG, 1995).

8. P. R. Johnson, 'Tectonic Map of Saudi Arabia and Adjacent Areas (Minist. Pet. Miner. Resour., Jiddah, 1998).

9. E. A. Koster, "Neotectonics," in The Physical Geography of Western Europe (Oxford Univ. Press, Oxford, 2005).

10. C. J. Kumanan, "Remote sensing revealed morphotectonic anomalies as a tool to neotectonic mapping experience from south India," 22nd Asian Conference on Remote Sensing, Singapore, 2001 (Centre for Remote Imaging, Sensing and Processing, Singapore, 2001). https://crisp.nus.edu.sg/ acrs2001/pdf/195kuman.pdf.

11. T. Mauduit and J. P. Brun, 1998. "Growth fault/rollover systems: Birth, growth, and decay," J. Geophys. Res.: Solid Earth 103, 18119-18136 (1998).

12. M. Markovic, R. Pavlovic, T. Cupkovic, and P. Zivkovic, "Structural pattern and neotectonic activity in the wider Majdanpek area, NE Serbia, Yugoslavia," Acta Montan. Slovaca 1, 151-158 (1996). 
13. C. L. Mello, C. M. S. Metelo, K. Suguio, and C. H. Kohler, "Quaternary sedimentation, neotectonics and evolution of the Doce river middle valley lake system (SE Brazil),” Rev. Inst. Geol., Sao Paulo 20, 29-36 (1999).

14. V. A. Obruchev, "Contemporary movements in the Earth crust," in Vol. 3 of The Encyclopedia of Geomorphology, Ed. by R. W. Faibridge (Reinhold, New York, 1968).

15. P. Kassler, "The structural and geomorphic evolution of the Persian Gulf," in The Persian Gulf, Ed. by B. H. Purser (Springer, Berlin, 1973), pp. 11-32. doi 10.1007/978-3642-65545-6

16. A. Rodríguez-Ramírez, E. Flores-Hurtado, C. Contreras, J. Villarías-Robles, G. Jiménez-Moreno, J. PérezAsensio, J. López-Sáez, S. Celestino-Pére, E. CerrilloCuenca, and A. León, "The role of neo-tectonics in the sedimentary infilling and geomorphological evolution of the Guadalquivir estuary (Gulf of Cadiz, SW Spain) during the Holocene," Geomorphology 219, 126-140 (2012). doi 10.1016/j.geomorph.2014.05.004

17. P. A. Pirazzoli, "Tectonics and neotectonics," in Encyclopedia of Coastal Science, Ed. by M. L. Schwartz (Springer, Berlin, 2005), Ch. 1. doi 10.1007/1-40203880-1_310

18. V. K Sissakian and S. F. Fouad, Geological Map of Iraq, Scale 1: 1000000, 3rd ed. (Iraq Geol. Surv., Baghdad, 2012).
19. V. K. Sissakian, A. D. Abdul Ahad, N. Al-Ansari, and S. Knutson, "Geomorphology, geology and tectonics of Jabal Sanam, South Iraq," J. Earth Sci. Geotech. Eng. 7 (3), 97-113 (2017).

20. V. K. Sissakian, A. T. Shehab, N. Al-Ansari, and S. Knutson, "New tectonic findings and its implication on locating oil fields in parts of Gulf Region," J. Earth Sci. Geotech. Eng. 7 (3), 51-75 (2017).

21. S. K. Tanoli, "Sedimentological evidence for the Late Holocene sea level change at the Enjefa Beach exposures of Kuwait, NW Arabian Gulf," Arab. J. Geosci. 8, 6063-6074 (2015). doi 10.1007/s12517-014-1577-6

22. United Nations Group of Experts on Geographical Names, Historical, Geographical and Legal Validity of the Name: PERSIAN GULF, Working Paper No. 61 of 26th Session, Vienna, Austria, 2006 (United Nations, 2006).

23. S. Y. Yacoub, "Geomorphology," in Geology of the Mesopotamia Plain, Spec. Is. No. 4 of Iraqi Bull. Geol. Min. (2011), pp. 7-32.

24. S. Y. Yacoub, "Stratigraphy," in Geology of the Mesopotamia Plain, Spec. Is. No. 4 of Iraqi Bull. Geol. Min. (2011), pp. 47-82.

Reviewer: V.G. Trifonov 